\title{
Review Article \\ Holistic Management: Misinformation on the Science of Grazed Ecosystems
}

\author{
John Carter, ${ }^{1}$ Allison Jones, ${ }^{2}$ Mary O'Brien, ${ }^{3}$ Jonathan Ratner, ${ }^{4}$ and George Wuerthner ${ }^{5}$ \\ ${ }^{1}$ Kiesha's Preserve, Paris, ID 83261, USA \\ ${ }^{2}$ Wild Utah Project, Salt Lake City, UT 84101, USA \\ ${ }^{3}$ Grand Canyon Trust, Flagstaff, AZ 86001, USA \\ ${ }^{4}$ Western Watersheds Project, Pinedale, WY 82941, USA \\ ${ }^{5}$ Foundation for Deep Ecology, Bend, OR 97708, USA
}

Correspondence should be addressed to John Carter; johncarter@hughes.net

Received 6 February 2014; Accepted 24 March 2014; Published 23 April 2014

Academic Editor: Lutz Eckstein

Copyright ( 2014 John Carter et al. This is an open access article distributed under the Creative Commons Attribution License, which permits unrestricted use, distribution, and reproduction in any medium, provided the original work is properly cited.

Over 3 billion hectares of lands worldwide are grazed by livestock, with a majority suffering degradation in ecological condition. Losses in plant productivity, biodiversity of plant and animal communities, and carbon storage are occurring as a result of livestock grazing. Holistic management (HM) has been proposed as a means of restoring degraded deserts and grasslands and reversing climate change. The fundamental approach of this system is based on frequently rotating livestock herds to mimic native ungulates reacting to predators in order to break up biological soil crusts and trample plants and soils to promote restoration. This review could find no peer-reviewed studies that show that this management approach is superior to conventional grazing systems in outcomes. Any claims of success due to HM are likely due to the management aspects of goal setting, monitoring, and adapting to meet goals, not the ecological principles embodied in HM. Ecologically, the application of HM principles of trampling and intensive foraging are as detrimental to plants, soils, water storage, and plant productivity as are conventional grazing systems. Contrary to claims made that HM will reverse climate change, the scientific evidence is that global greenhouse gas emissions are vastly larger than the capacity of worldwide grasslands and deserts to store the carbon emitted each year.

\section{Introduction}

Lands grazed by livestock include 3.4 billion ha worldwide with $73 \%$ estimated to be suffering soil degradation [1]. The solution presented during Allan Savory's February 2013 TED Talk was to use holistic management (HM) to reverse desertification and climate change [2]. He reported that we are creating "too much bare ground" (1:30 in video) in the arid areas of the world and, as a consequence, rainfall runs off or evaporates, soils are damaged, and carbon is released back to the atmosphere. Grasslands, even in high rainfall areas, may contain large areas of bare ground with a crust of algae, leading to increased runoff and evaporation. Desertification is caused by livestock, "overgrazing the plants, leaving the soil bare, and giving off methane" (4:20 in video).
HM is also called holistic resource management, time controlled grazing, Savory grazing method, or short-duration grazing. It is designed to mimic the behavior of grazing animals that are regulated by their predators to gather in large groups. As Savory puts it [2], "What we had failed to understand was that these seasonal humidity environments of the world, the soil and the vegetation developed with very large numbers of grazing animals, and that these grazing animals developed with ferocious pack-hunting predators. Now, the main defense against pack-hunting predators is to get into herds, and the larger the herd, the safer the individuals. Now, large herds dung and urinate all over their own food, and they have to keep moving, and it was that movement that prevented the overgrazing of plants, while the periodic trampling ensured good cover of the soil, as we 
see where a herd has passed." (9:28 in video). In view of the large amount of attention received from the TED talk it is important to examine the validity of Savory's claims.

Savory's writings lack specifics that could be used for implementation of HM or for scientific testing. Details regarding setting of stocking rates, allowable use by livestock, amount of rest needed for recovery, or ecological criteria to be met for biodiversity, sustainability, wildlife, and watershed protection are absent [3-7]. These publications by Savory and his colleagues show that HM is based on the following assumptions: (1) plant communities and soils of the arid, semiarid, and grassland systems of the world evolved in the presence of large herds of animals regulated by their predators; (2) grasses in these areas will become decadent and die out if not grazed by these large herds or their modern day equivalent, livestock; (3) rest from grazing by these large herds of livestock will result in grassland deterioration; (4) large herds are needed to break up decadent plant material and soil crusts and trample dung, urine, seeds, and plant material into the soil, promoting plant growth; and (5) high intensity grazing of these lands by livestock will reverse desertification and climate change by increasing production and cover of the soil, thereby storing more carbon.

We address these five assumptions of HM with a focus on western North American arid and semiarid ecosystems, principally in the desert, steppe, grassland, and open conifer woodland biomes as described by [8]. We use the broad term, grassland, to be inclusive of these types.

\section{Are Western North American Ecosystems Adapted to Herds of Large Hooved Animals?}

Not all of today's grasslands, arid, and semiarid systems evolved with herds of large, hooved animals. The Great Plains of North America and subtropical grasslands in Africa that receive moisture during the long, warm, and moist growing season historically supported millions of herbivores [9-11]. Lands west of the Continental Divide of the USA, including the Great Basin, Sonoran, Mojave, and Colorado Plateau deserts, along with the Palouse Prairie grasslands of eastern Washington, western Montana, and northern Idaho, did not evolve with significant grazing pressure from bison (Bison bison) $[9,12,13]$. Though bison were abundant east of the Rockies on the Great Plains, they only occurred in limited numbers across western Wyoming, northeastern Utah, and southeastern Idaho $[12,14]$. These low numbers and patchy occurrence would not have played the same ecological role as in the plains. Historically, pronghorn antelope (Antilocapra americana) were more widespread than bison west of the Rockies, but these animals are smaller and lighter than bison and are not ecologically comparable [9]. Evidence for this general lack of large herds of grazing animals west of the Rockies also includes the lack of native dung beetles in the region. Whereas 34 native species of dung beetle (g. Onthophagus) are found east of the Rockies on the plains where bison were numerous, none are found west of the Rockies [15].
The supposition that current western North American plant communities are adapted to livestock grazing because the region supported a diverse herbivore fauna during the Pleistocene epoch ignores that the plant communities have changed in the intervening time [16]. There was rapid evolutionary change following the Pleistocene glaciations in North America with "the establishment of open xeric grasslands in the west central part of the USA ... less than 10,000 years ago" [17]. Many of the grasses of the Pleistocene have disappeared from the plains and western USA and the fauna of the Pleistocene was altered by the arrival of bison from Eurasia. These were destructive to long-leaved bunchgrasses found west of the Rockies, while the rhizomatous grasses found east of the Rockies in the prairies were more resistant to their grazing pressure. These rhizomatous grasses are the types found in the prairies of the central and western USA in conjunction with fossil remains of bison. In summary, the western USA of the Pleistocene is not the western USA of today. The climate was much wetter and cooler and the vegetation more mesic in the Pleistocene than today $[8,18]$. The drier periods following the Pleistocene as temperatures warmed have altered soil conditions and fire cycles and contributed to the changing flora $[19,20]$.

Grasslands cover large areas that could support forests but are maintained by grasses outcompeting woody species for belowground resources and providing fuel for fires that limit encroachment of woody species [21]. Climate change and increasing $\mathrm{CO}_{2}$ concentrations have been implicated in the post industrial expansion of woody species and invasive species into grasslands; however, studies from paired locations in grasslands have shown that under similar climatic and $\mathrm{CO}_{2}$ environments, herbivory by domestic livestock has caused the shifts in woody species and increased invasive species $[20,22,23]$. Elevated $\mathrm{CO}_{2}$ and climate warming appear to contribute to, but do not explain, the shrub encroachment in these semiarid areas which is due to intensive grazing by domestic livestock [24].

Conclusion. Western US ecosystems outside the prairies in which bison occurred are not adapted to the impact of large herds of livestock. Recent changes to these grassland ecosystems result from herbivory by domestic livestock which has altered fire cycles and promoted invasive species at the expense of native vegetation.

\section{Do Grasses Senesce and Die If Not Grazed by Livestock?}

A major premise of $\mathrm{HM}$ is that grass species depend on large grazing ungulates in some way, and thus grasses become moribund and die if not grazed, leading to deterioration or eventual loss of the entire grass community [6]. The dead or dormant residual leaves and stalks that remain attached to ungrazed grasses at the end of each growing season can be deceptive. The plants are still alive and healthy, with living buds at the plant base. Bunchgrass canopies collect snow and funnel rainwater to the plant base and soil and increase infiltration [25]. The plants and dead leaves in contact with the soil reduce overland flow and erosion [26]. Plant 
canopies moderate temperature and protect the growing points from temperature extremes [27]. The standing dead litter provides cover and food for wildlife species including large and small mammals, ground-living birds, and insects. The loss of these leaves and stems through heavy grazing by livestock which occurs under HM destroys these natural attributes.

Grasses with attached dead leaves are more productive than grasses from which the dead leaves have been removed. Loss of these dead tissues to grazers increases thermal damage to the growing shoots and reduces the vigor of the entire plant [28]. Dead leaves and flowering stalks on ungrazed grasses inhibit livestock grazing, allowing those grasses to grow larger than their neighbors [29]. Grazing and trampling by domestic livestock damage plants in natural plant communities [30-32], reduce forage production as stocking rates increase [33], and can lead to simplification of plant communities, establishment of woody vegetation in grasslands, and regression to earlier successional stages [20] or conversion to invasive dominated communities [23] and altered fire cycles [20]. In contrast to the assertion that grasses will die if not grazed by livestock, bunchgrasses in arid environments are more likely to die if they are heavily grazed by domestic animals [34, 35].

Conclusion. Grasses, particularly bunchgrasses, have structure that protects growing points from damage, harvests water, and protects the soil at the plant base. Removal of the standing plant material exposes the growing points, leading to loss or replacement by grazing tolerant species, including invasives.

\section{Does Rest Cause Grassland Deterioration?}

Another principle of HM is that grasslands and their soils deteriorate from overrest, a term that implies insufficient grazing by livestock. However, grasslands that have never been grazed by livestock have been found to support high cover of grasses and forbs. Relict sites throughout the western USA, such as on mesa tops, steep gorges, cliff sides, and even highway rights of way, which are inaccessible to livestock or most ungulates, can retain thriving bunchgrass communities [36-38]. For example, herbaceous growth was vigorous on never-grazed Jordan Valley kipukas in southeast Oregon [37] and on a once-grazed butte called The Island in south central Oregon [36]. Published comparisons of grazed and ungrazed lands in the western USA have found that rested sites have larger and more dense grasses, fewer weedy forbs and shrubs, higher biodiversity, higher productivity, less bare ground, and better water infiltration than nearby grazed sites. These reports include 139 sites in south Dakota [39], as well as sites that had been rested for 18 years in Montana [40], 30 years in Nevada [41], 20-40 years in British Columbia [42], 45 years in Idaho [43], and 50 years in the Sonoran Desert of Arizona [44]. None of the above studies demonstrated that long periods of rest damaged native grasslands. A list and description of such sites can be found in $[45]$.
The HM misinterpretation of the natural history of grazed and ungrazed grasslands is apparent in Savory's description of the Appleton-Whittell Research Ranch in southeastern Arizona [6]. This ranch has been protected from livestock grazing since 1968 with the grasses on the ranch described by Savory as becoming "moribund" (page 211), with "bare spots opening up" (page 211). In contrast to those claims, plant species richness on the ranch increased from 22 species in 1969 to 49 species in 1984, while plant cover increased from $29 \%$ in 1968 to $85 \%$ in 1984 [46]. Total grass cover on the ranch was significantly higher on ungrazed sites when compared to grazed sites $(P<0.01)$ [47]. These well designed studies produced quantitative data showing that the HM view of the ranch is not the case.

Conclusion. Contrary to the assumption that grasses will senesce and die if not grazed by livestock, studies of numerous relict sites, long-term rested sites, and paired grazed and ungrazed sites have demonstrated that native plant communities, particularly bunchgrasses, are sustained by rest from livestock grazing.

\section{Is Hoof Action Necessary for Grassland Health?}

A key premise of $\mathrm{HM}$ is that livestock can be made to emulate native ungulate responses to predators by moving them frequently in large numbers and tight groups. This promotes very close cropping which is said to benefit grasses and other forage, as well as hoof action that breaks up soil crusts, increases infiltration, plants seeds, and incorporates plant material, manure, and urine into the soil [6]. Other than bison in the plains states, the evidence indicates a low frequency of large hooved mammals in the western USA during pre-Columbian times [48], so the opportunity for hoof action to sustain grasslands and deserts appears limited at best. In contrast to HM claims, elk (Cervus canadensis), mule deer (Odocoileus hemionus), and other ungulates may avoid areas where predators have an advantage in capturing them [49]. Avoidance is not the same as a panicked flight or tight groupings of animals promoting hoof action. Rather, the major response is greater vigilance and sometimes avoidance of risky areas. While the presence of wolves (Canis lupus) affects elk behavior by reducing browsing on willows and aspen [50], snow depth and other ecological needs appear to outweigh the effect of wolves leading to grazing and browsing in areas of higher risk $[51,52]$. We found no documentation of native animal responses to predators generating hoof action or herd effect in tight groupings in the western USA.

Soils in arid and semiarid grasslands often have significant areas covered by biological crusts [53-55]. These are made up of bacteria, cyanobacteria, algae, mosses, and lichens and are essential to the health of these grasslands. Biological crusts stabilize soils, increase soil organic matter and nutrient content, absorb dew during dry periods, and fix nitrogen [53, 56-60]. Crusts enhance soil stability and reduce water runoff by producing more microcatchments on soil surfaces. They increase water absorbing organic matter, improve nutrient flow, germination and establishment for 
some plants, while dark crusts may stimulate plant growth by producing warmer soil temperatures and water uptake in cold deserts [61]. Some crusts are hydrophobic, shedding water [60]. Biological soil crusts are fragile, highly susceptible to trampling [61-63], and are slow to recover from trampling impacts [64]. Loss of these crusts results in increased erosion and reduced soil fertility. The loss of crusts in the bunchgrass communities of the western USA may be largely responsible for the widespread establishment of cheatgrass and other exotic annuals $[23,58,65]$. The rapid spread of introduced weeds throughout the arid western USA is estimated at over 2000 hectares per day [66], largely due to livestock disturbance.

The HM assumption that increasing hoof action will increase infiltration has been disproven. Livestock grazing can compact soil, reduce infiltration, and increase runoff, erosion, and sediment yield [67-71]. Major increases in erosion and runoff occur under normal stocking when comparing grazed to ungrazed sites $[68,71-74]$. Extensive literature reviews report the negative impacts of livestock grazing on soil stability and erosion [75-77]. For example, a study of wet and dry meadows in Oregon found the infiltration rate in ungrazed dry meadows was 13 times greater and 2.3 times greater in ungrazed wet meadows, compared to similar grazed meadows [78].

Hoof action is not needed to increase soil fertility and decomposition of litter. It is well-established that soil protozoa, arthropods, earthworms, microscopic bacteria, and fungi decompose plant and animal residues in all environments $[79,80]$. Even the driest environments contain 100 million to one billion decomposing bacteria and tens to hundreds of meters of fungal hyphae per gram of soil [81]. Brady and Weil [80] discuss the importance of mammals in the decay process, mentioning burrowing mammals, but not large grazers such as cattle and bison. Removal of plant biomass and lowered production resulting from livestock grazing can reduce fertility and organic content of the soil [70, 82-84].

Conclusion. We found no evidence that hoof action as described by Savory occurs in the arid and semiarid grasslands of the western USA which lacked large herds of ungulates such as bison that occurred in the prairies of the USA or the savannahs of Africa. No benefits of hoof action were found. To the contrary, hoof action by livestock has been documented to destroy biological crusts, a key component in soil protection and nutrient cycling, thereby increasing erosion rates and reducing fertility, while, increasing soil compaction and reducing water infiltration.

\section{Can Grazing Livestock Increase Carbon Storage and Reverse Climate Change?}

Among the most recent HM claims is that livestock grazing will lead to sequestration of large amounts of carbon, thus potentially reversing climate change [2]. However, any increased carbon storage through livestock grazing must be weighed against the contribution of livestock metabolism to greenhouse gas emissions due to rumen bacteria methane emissions, manure, and fossil fuel use across the production chain $[85,86]$. Nitrous oxide, 300 times more potent than methane in trapping greenhouse gases [87], is also produced and released with livestock production. The livestock industry's contribution to greenhouse gases also includes $\mathrm{CO}_{2}$ released by conversion of forests to grasslands for the purpose of grazing [86].

Worldwide, livestock production accounts for about 37 percent of global anthropogenic methane emissions and 65 percent of anthropogenic nitrous oxide emissions with as much as $18 \%$ of current global greenhouse gas emissions $\left(\mathrm{CO}_{2}\right.$ equivalent) generated from the livestock industry [85]. It is estimated that livestock production, byproducts, and other externalities account for 29.5 billion metric tons of $\mathrm{CO}_{2}$ per year or 51 percent of annual worldwide greenhouse gas emissions from agriculture [88]. Lower amounts of greenhouse gas emissions due to livestock may be estimated by using narrower definitions of livestock-related emissions that include feed based emissions only and exclude externalities [89].

Some suggest that grass-fed beef is a superior alternative to beef produced in confined animal feeding operations [90]. However, grass provides less caloric energy per pound of feed than grain and, as a consequence, a grass-fed cow's rumen bacteria must work longer breaking down and digesting grass in order to extract the same energy content found in grain, while the bacteria in its rumen are emitting methane [89]. Comparisons of pasture-finished and feedlot-finished beef in the USA found that pasture-finished beef produced $30 \%$ more greenhouse gas emissions on a live weight basis [91].

It is estimated that three times as much carbon resides in soil organic matter as in the atmosphere [92], while grasslands and shrublands have been estimated to store 30 percent of the world's soil carbon with additional amounts stored in the associated vegetation [93]. Long term intensive agriculture can significantly deplete soil organic carbon [94] and past livestock grazing in the United States has led to such losses $[95,96]$. Livestock grazing was also found to significantly reduce carbon storage on Australian grazed lands while destocking currently grazed shrublands resulted in net carbon storage [97]. Livestock-grazed sites in Canyonlands National Park, Utah, had 20\% less plant cover and $100 \%$ less soil carbon and nitrogen than areas grazed only by native herbivores [98]. Declines in soil carbon and nitrogen were found in grazed areas compared to ungrazed areas in sage steppe habitats in northeastern Utah [84]. As grazing intensity increased, mycorrhizal fungi at the litter/soil interface were destroyed by trampling, while ground cover, plant litter, and soil organic carbon and nitrogen decreased [84]. A review by Beschta et al. [20] determined that livestock grazing and trampling in the western USA led to a reduction in the ability of vegetation and soils to sequester carbon and also led to losses in stored carbon.

Conclusion. Livestock are a major source of greenhouse gas emissions. Livestock removal of plant biomass and altering of soil properties by trampling and erosion causes loss of carbon storage and nutrients as evidenced by studies in grazed and ungrazed areas. 


\section{What Is the Evidence That Holistic Management Does Not Produce the Claimed Effects?}

$\mathrm{HM}$ is a management system that includes setting goals, monitoring, and adapting in order to continually move towards the goals established by the producer [6]. This more goal-oriented and adaptive management aspect of the HM system, its promise of environmental benefits, and increased production make it attractive to many ranchers [99]. However, researchers who have studied HM in South Africa and Zimbabwe, where Savory originated his theories, have rejected many of HM's underlying assumptions and found that HM approaches result in reduced water infiltration into the soil, increased erosion, reduced forage production, reduced soil organic matter and nitrogen, reduced mineral cycling, and increased soil bulk density [82, 100, 101].

In a recent evaluation of HM by Briske et al. [102], three of its principle claims were addressed: (1) all nonforested lands are degraded; (2) these lands can store all fossil fuel carbon in the atmosphere; and (3) intensive grazing is necessary to prevent the degradation. The authors pointed out that there are well managed lands that are not degraded; deserts are a consequence of climate and soils as well as improper management; and degradation is largely a function of growing populations of humans and livestock, land fragmentation, and other societal issues. As to the claim that these nonforested lands could store all the carbon emissions that humans produce, the researchers show that the potential carbon sequestration of these lands is only about one to two billion metric tons per year (mtpy), a small fraction of global carbon emissions of 50 billion mtpy. They further point out that these lands would have to produce much larger vegetation biomass than they are capable of producing in order to sequester human-caused carbon emissions and that much of the carbon is released back to the atmosphere through respiration as $\mathrm{CO}_{2}$. They note that grass cover increases dramatically with rest and intensive grazing delays this recovery; many desert grassland soils are sandy, so hoof action does not increase infiltration; and biological crusts stabilize these soils and protect them from wind erosion and carbon loss.

A review of short-duration grazing studies in the western USA by Holechek et al. [83] included locations in the more arid western states as well as prairie types. The researchers found that this grazing system, which is equated with HM, resulted in decreased infiltration, increased erosion, and reduced soil organic matter and nitrogen. Forage production and range condition were similar under short-duration and continuous grazing with the same stocking rates. Under short-duration grazing, standing crop of forage declined as stocking rates increased, while bare ground and vegetation composition were a function of stocking rate as opposed to grazing system. Grazing distribution was not improved over continuous grazing and the claims for hoof action and improved range condition under increased stocking rates and densities were not realized [83]. Another review of grazing systems by Briske et al. [103], including HM, versus continuous grazing concluded that plant and animal production were equal or greater in continuous grazing than in rotational grazing systems.

Even though the ecosystems of the Great Plains states evolved with the pressure of bison, Holechek et al. [83] and Briske et al. [103] found that HM did not differ from traditional, season-long grazing for most dependent variables compared. Studies commonly held up as supporting HM [104-108] used HM paddocks that were grazed with light to moderate grazing, not the heavy grazing that Savory recommends. Further, long-term range studies have shown that it is reductions in stocking rate that lead to increased forage production and improvements in range condition, not grazing system $[33,109,110]$. While HM advocates allowing recovery to take place following grazing, recovery can take many years to decades even under total rest from livestock, but it does occur $[43,111]$. Native, western USA bunchgrass species such as bluebunch wheatgrass (Pseudoroegneria spicata) and Idaho fescue (Festuca idahoensis) are sensitive to defoliation and can require long periods (years) of rest following each period of grazing in order to restore their vigor and productivity $[34,35]$.

Conclusion. Studies in Africa and the western USA, including the prairies which evolved in the presence of bison, show that $\mathrm{HM}$, like conventional grazing systems, does not compensate for overstocking of livestock. As in conventional grazing systems, livestock managed under HM reduce water infiltration into the soil, increase soil erosion, reduce forage production, reduce range condition, reduce soil organic matter and nutrients, and increase soil bulk density. Application of HM cannot sequester much, let alone all the greenhouse gas emissions from human activities because the sequestration capacity of grazed lands is much less than annual greenhouse gas emissions.

\section{What about Riparian Areas and Biodiversity?}

In the western USA, riparian areas are rare and valuable ecological systems supporting a disproportionate number of species and providing many ecosystem services [112]. How does HM, with its emphasis on high stocking rates and trampling, affect these systems? Soil compaction from livestock is a common and widespread problem in grazed riparian areas, reducing infiltration rates and water storage and increasing surface runoff and soil erosion during storm events $[78,112]$. Soil compaction from livestock increases with increased numbers, as in an HM application [70]. Livestock grazing in riparian areas reduces willow and herbaceous production and canopy cover of shrubs and grasses compared to ungrazed controls [113]. The most effective way to restore damaged riparian areas is to remove livestock [110, 112].

We found very little information about total number of plant, animal, or invertebrate species present when HM is compared to other grazing methods or nongrazed areas, and, further, what proportion of total plant species or total cover of plant species was native or nonnative. Moreover, we did not see other biodiversity considerations addressed in any of the published studies investigating HM. Rotational 
grazing systems do not improve range condition and plant production over conventional grazing systems [83, 103], while stocking rate is considered the most important variable affecting vegetation production and range condition [33]. Range condition is determined based on the current plant community composition and production as compared to the potential natural community [114]. The relative composition of Increasers, those plants with tolerance for grazing, Decreasers, those plants with low tolerance for grazing, and Invasives, those plants occupying a site that are grazing tolerant and nonnative, forms the basis of the determination of condition. Higher range condition ratings reflect greater similarity to the native plant community for a site [115]. This basic concept reflects the biodiversity of the native plant community, which necessarily declines as range condition declines. Application of HM with its large herd size and density of use, like other grazing systems with high stocking rates, must necessarily decrease native plant diversity and productivity. This affects the animal communities accordingly as habitat structure and production are altered.

A review, by Fleischner [76], of the effects of livestock grazing on plant and animal communities in the western USA found that livestock grazing reduced species richness and abundance of plants, small mammals, birds, reptiles, insects, and fish compared to conditions following removal of livestock. A quantitative review by Jones [77] of published studies of ecosystem attributes in North American arid ecosystems affected by livestock grazing, compared to ungrazed conditions, found decreases in rodent species richness and diversity and vegetation diversity in the grazed areas. Livestock grazing-induced simplified plant communities in western USA arid and semiarid lands have negative effects on pollinators, birds, small mammals, amphibians, wild ungulates, and other native wildlife [20]. Riparian songbird abundance increases as riparian systems recover after livestock exclusion $[116,117]$, while overall biodiversity increases under long term rest from livestock grazing $[46,47,118]$. Invasives such as cheatgrass (Bromus tectorum) are favored and increase in abundance in the presence of livestock grazing $[23,65]$ and are inversely related to abundance of native perennial grasses [43].

Conclusion. HM does not address riparian areas and biodiversity with its focus on livestock production, although operators could choose these as goals. We have seen no studies of HM impacts on riparian areas and biodiversity, although livestock grazing impacts on riparian areas and biodiversity have been well documented. Livestock degrade riparian areas by removal of streamside vegetation, reduction of cover and food for fish and wildlife, and soil compaction, erosion, and sedimentation. These impacts lead to loss of native fish and wildlife populations. Studies in areas from which livestock have been removed demonstrate increases in diversity and abundance of birds, mammals, insects, and fish.

\section{Is Scientific Evidence Important?}

Effectiveness studies of HM have been undertaken by ranchers and farmers who were selected because of their commitment to HM [119]. In other words, such studies were neither experimental nor were the participants randomly selected. Livestock producers who may have had negative experiences with HM were not included in the studies. Nearly all of the support and confirmation for HM come from articles developed at the Savory Institute or testimonials by practitioners. Most of the published literature that attempts to rigorously test HM in any scientific fashion does not support its principal assumptions.

Holechek et al. [83] stated that "No grazing approach, including that of Savory, will overcome the adverse effects of drought and/or chronic heavy stocking on forage production." These researchers were also critical of government agencies for adopting these unproven theories rather than basing management on "scientifically proven range management practices and principles" [83] (page 25). Briske et al. [103] stated,

the rangeland profession has become mired in confusion, misinterpretation, and uncertainty with respect to the evaluation of grazing systems and the development of grazing recommendations and policy decisions. We contend that this has occurred because recommendations have traditionally been based on perception, personal experience, and anecdotal interpretations of management practices, rather than evidencebased assessments of ecosystem responses. [103] (page 11).

Briske et al. [102] state, "Mr. Savory's attempts to divide science and management perspectives and his aggressive promotion of a narrowly focused and widely challenged grazing method only serve to weaken global efforts to promote rangeland restoration and C sequestration." [102] (page 74).

Conclusion. Studies supporting HM have generally come from the Savory Institute or anecdotal accounts of HM practitioners. Leading range scientists have refuted the system and indicated that its adoption by land management agencies is based on these anecdotes and unproven principles rather than scientific evidence. When addressing the application of $\mathrm{HM}$ or any other grazing systems, practitioners, including agencies managing public lands, private livestock operations, and scientists, should (1) consider inclusion of watershedscale ungrazed reference areas of suitable size to encompass the plant and soil communities found in the grazed area, (2) define ecological (plant, soil, and animal community) and production (livestock) criteria on which to base quantitative comparisons, (3) use sufficient replication in studies, (4) and include adequate quality control of methods. Economic analysis of grazing systems should compare all expenditures with income, including externalized costs such as soil loss, water pollution, reduction of water infiltration, and carbon emissions and capture.

\section{Management Implications}

This review shows that the underlying assumptions of HM regarding the evolutionary adaptation of western North 
American landscapes to large herds of hooved animals only applies to prairie grasslands and that most arid and semiarid areas of western North America are not adapted to their impacts. The premise that rest results in degradation of grassland ecosystems by allowing biological crusts to persist and grasses to senesce and die has been disproven by a large body of research. Reliance on hoof action to promote recovery by trampling seeds and organic matter into the soil and breaking up soil crusts needs to be considered in the context of increased soil compaction, lower infiltration rates, and the destruction of biological crusts that normally provide long-term stability to soil surfaces, enhance water retention, and promote nutrient cycling. The use of HM in an attempt to capture atmospheric greenhouse gases and incorporate them into soils and plant communities, thereby reducing climate change effects, is demonstrably impossible because the nonforested grazed lands of the world do not have the capacity to sequester this amount of emissions. Even in the prairie regions of the United States, which are evolutionarily adapted to large herbivores such as bison, research indicates that not only does HM not produce results superior to conventional season-long grazing, but also that stocking rate, rest, and livestock exclusion represent the best mechanisms for restoring grassland productivity, ecological condition, and sustainability. Various studies indicate livestock grazing reduces biodiversity of native species and degrades riparian areas, with nearly all studies finding livestock exclusion to be the most effective, reliable means to restore degraded riparian areas. Claims of the benefits of HM or other grazing systems should be validated by quantitative, scientifically valid studies.

\section{Conflict of Interests}

The authors declare that there is no conflict of interests regarding the publication of this paper.

\section{Funding}

Research was funded by the Foundation for Deep Ecology, Grand Canyon Trust, Kiesha's Preserve, Western Watersheds Project and Wild Utah Project.

\section{Acknowledgment}

Joy Belsky (1944-2001), Range Ecologist, who made available a draft analysis of holistic management before her death, provided us with much of the material presented here.

\section{References}

[1] E. Gabathuler, H. Liniger, C. Hauert, and M. Giger, Benefits of Sustainable Land Management, World Overview of Conservation Approaches and Technologies, Center for Development and Environment, University of Bern, Bern, Switzerland, 2009.

[2] A. Savory, "How to fight desertification and reverse climate change," 2013, http://www.ted.com/talks/allan_savory_how_to _green_the_world_s_deserts_and_reverse_climate_change.html.
[3] A. Savory and S. D. Parsons, "The Savory grazing method," Rangelands, vol. 2, pp. 234-237, 1980.

[4] A. Savory, "The Savory grazing method or holistic resource management," Rangelands, vol. 5, pp. 155-159, 1983.

[5] A. Savory, Holistic Resource Management, Island Press, Washington, DC, USA, 1988.

[6] A. Savory and J. Butterfield, Holistic Management: A New Framework for Decision Making, Island Press, Washington, DC, USA, 1999.

[7] C. J. Hadley, "The wild life of Allan Savory," Rangelands, vol. 22, pp. 6-10, 2000.

[8] R. S. Thompson and K. H. Anderson, "Biomes of western North America at 18,000, 6000 and $0{ }^{14} \mathrm{C}$ yr BP reconstructed from pollen and packrat midden data," Journal of Biogeography, vol. 27, no. 3, pp. 555-584, 2000.

[9] R. N. Mack and J. N. Thompson, "Evolution in steppe with few large hooved mammals," American Naturalist, vol. 119, no. 6, pp. 757-773, 1982.

[10] A. R. E. Sinclair and M. Norton-Griffiths, Serengeti: Dynamics of an Ecosystem, University of Chicago Press, 1979.

[11] A. R. E. Sinclair, S. A. R. Mduma, J. G. C. Hopcraft, J. M. Fryxell, R. Hilborn, and S. Thirgood, "Long-term ecosystem dynamics in the serengeti: lessons for conservation," Conservation Biology, vol. 21, no. 3, pp. 580-590, 2007.

[12] R. Daubenmire, "The western limits of the range of the American bison," Ecology, vol. 66, no. 2, pp. 622-624, 1985.

[13] G. Wuerthner, "Are cows just domestic bison? Behavioral and habitat use differences between cattle and bison," in Proceedings of an International Symposium on Bison Ecology and Management in North America, L. Irby, L. Knight, and J. Knight, Eds., pp. 374-383, Bozeman, Mont, USA, June 1998.

[14] F. G. Roe, The North American Buffalo: A Critical Study of the Species in Its Wild State, University of Toronto Press, Toronto, Calif, USA, 1951.

[15] J. F. Howden, "Some possible effects of the Pleistocene on the distributions of North American Scarabaeidae (Coleoptera)," Canadian Entomologist, vol. 98, no. 11, pp. 1177-1190, 1966.

[16] J. W. Burkhardt, Herbivory in the Intermountain West, vol. 58 of Station Bulletin, University of Idaho Forest, Wildlife and Range Experiment Station, Moscow, Idaho, USA, 1996.

[17] J. M. J. de Wet, "Grasses and the culture history of man," Annals Missouri Botanical Garden, vol. 68, no. 1, pp. 87-104, 1981.

[18] H. Wanner, J. Beer, J. Bütikofer et al., "Mid- to Late Holocene climate change: an overview," Quaternary Science Reviews, vol. 27, no. 19-20, pp. 1791-1828, 2008.

[19] D. K. Grayson, "Mammalian responses to middle Holocene climatic change in the Great Basin of the western United States," Journal of Biogeography, vol. 27, no. 1, pp. 181-192, 2000.

[20] R. L. Beschta, D. L. Donahue, A. DellaSala et al., "Adapting to climate change on western public lands: addressing the ecological effects of domestic, wild, and feral ungulates," Environmental Management, vol. 51, no. 2, pp. 474-491, 2012.

[21] W. J. Bond, "What limits trees in C4 grasslands and savannas?" Annual Review of Ecology, Evolution, and Systematics, vol. 39, pp. 641-659, 2008.

[22] S. Archer, D. S. Schimel, and E. A. Holland, "Mechanisms of shrubland expansion: land use, climate or $\mathrm{CO}_{2}$ ?" Climatic Change, vol. 29, no. 1, pp. 91-99, 1995.

[23] M. D. Reisner, J. B. Grace, D. A. Pyke, and P. S. Doescher, "Conditions favoring Bromus tectorum dominance of endangered 
sagebrush steppe ecosystems," Journal of Applied Ecology, vol. 50, no. 4, pp. 1039-1049, 2013.

[24] O. W. van Auken, "Shrub invasions of North American semiarid grasslands," Annual Review of Ecology and Systematics, vol. 31, pp. 197-215, 2000.

[25] G. W. Gee, P. A. Beedlow, and R. L. Skaggs, "Water balance," in Shrub-Steppe Balance and Change in a Semi-Arid Terrestrial Ecosystem, W. H. Rickard, L. E. Rogers, B. E. Vaughan, and S. F. Liebetrau, Eds., pp. 61-81, Elsevier, New York, NY, USA, 1988.

[26] W. H. Wischmeier and D. D. Smith, Predicting Rainfall Erosion Losses: A Guide to Conservation Planning, vol. 537 of Agriculture Handbook, US Department of Agriculture, Washington, DC, USA, 1978.

[27] W. T. Hinds and W. H. Rickard, "Soil temperatures near a desert steppe shrub," Northwest Science, vol. 42, pp. 5-8, 1968.

[28] R. H. Sauer, "Effect of removal of standing dead material on growth of Agropyron spicatum," Journal of Range Management, vol. 31, no. 2, pp. 121-122, 1978.

[29] D. Ganskopp, R. Angell, and J. Rose, "Response of cattle to cured reproductive stems in a caespitose grass," Journal of Range Management, vol. 45, no. 4, pp. 401-404, 1992.

[30] L. Ellison, "Influence of grazing on plant succession of Rangelands," The Botanical Review, vol. 26, no. 1, pp. 1-78, 1960.

[31] A. J. Belsky, "Does herbivory benefit plants? A review of the evidence," American Naturalist, vol. 127, no. 6, pp. 870-892, 1986.

[32] E. L. Painter and A. J. Belsky, "Application of herbivore optimization theory to rangelands of the western United States," Ecological Appplications, vol. 3, no. 1, pp. 2-9, 1993.

[33] J. L. Holechek, H. Gomez, F. Molinar, and D. Galt, "Grazing studies: what we've learned," Rangelands, vol. 21, no. 2, pp. 12-16, 1999.

[34] W. F. Mueggler, "Rate and pattern of vigor recovery in Idaho fescue and bluebunch wheatgrass," Journal of Range Management, vol. 28, no. 3, pp. 198-204, 1975.

[35] L. D. Anderson, Bluebunch Wheatgrass Defoliation, Effects and Recovery-A Review, vol. 91-2 of BLM Technical Bulletin, Bureau of Land Management, Idaho State Office, Boise, Idaho, USA, 1991.

[36] R. S. Driscoll, "A relict area in the central Oregon juniper zone," Ecology, vol. 45, no. 2, pp. 345-353, 1964.

[37] R. R. Kindschy, "Pristine vegetation of the Jordan Crater kipukas: 1978-1991," in Proceedings-Ecology and Management of Annual Rangelands, S. B. Monsen and S. G. Kitchen, Eds., INT-GTR-313, pp. 85-88, US Department of Agriculture, Forest Service, Boise, Idaho, USA, May 1992.

[38] N. Ambos, G. Robertson, and J. Douglas, "Dutchwoman butte: a relict grassland in central Arizona," Rangelands, vol. 22, no. 2, pp. 3-8, 2000.

[39] D. F. Costello and G. T. Turner, "Vegetation changes following exclusion of livestock from grazed ranges," Journal of Forestry, vol. 39, pp. 310-315, 1941.

[40] A. B. Evanko and R. A. Peterson, "Comparisons of protected and grazed mountain rangelands in southwestern Montana," Ecology, vol. 36, no. 1, pp. 71-82, 1955.

[41] J. H. Robertson, "Changes on a sagebrush-grass range in Nevada ungrazed for 30 years," Journal of Range Management, vol. 24, no. 5, pp. 397-400, 1971.

[42] A. McLean and E. W. Tisdale, "Recovery rate of depleted range sites under protection from grazing," Journal of Range Management, vol. 25, no. 3, pp. 178-184, 1972.
[43] J. E. Anderson and R. S. Inouye, "Landscape-scale changes in plant species abundance and biodiversity of a sagebrush steppe over 45 years," Ecological Monographs, vol. 71, no. 4, pp. 531-556, 2001.

[44] J. Blydenstein, C. R. Hungerford, G. I. Day, and R. R. Humphrey, "Effect of domestic livestock exclusion on vegetation in the Sonoran Desert," Ecology, vol. 38, no. 3, pp. 522-526, 1957.

[45] G. Wuerthner and M. Matteson, "A guide to livestock-free landscapes," in Welfare Ranching: The Subsidized Destruction of the American West, G. Wuerthner and M. Mattson, Eds., pp. 327-329, Island Press, Washington, DC, USA, 2004.

[46] W. W. Brady, M. R. Stromberg, E. F. Aldon, C. D. Bonham, and S. H. Henry, "Response of a semidesert grassland to 16 years of rest from grazing," Journal of Range Management, vol. 42, no. 4, pp. 284-288, 1989.

[47] C. E. Bock, J. H. Bock, W. R. Penney, and V. M. Hawthorne, "Responses of birds, rodents, and vegetation to livestock exclosure in a semidesert grassland site," Journal of Range Management, vol. 37, no. 3, pp. 239-242, 1984.

[48] W. J. Ripple and B. van Valkenburgh, "Linking top-down forces to the pleistocene megafaunal extinctions," BioScience, vol. 60, no. 7, pp. 516-526, 2010.

[49] J. W. Laundré, L. Hernández, and W. J. Ripple, "The landscape of fear: ecological implications of being afraid," The Open Ecology Journal, vol. 3, no. 2, pp. 1-7, 2010.

[50] C. Eisenberg, S. T. Seager, and D. E. Hibbs, "Wolf, elk, and aspen food web relationships: context and complexity," Forest Ecology and Management, vol. 299, pp. 70-80, 2013.

[51] S. Creel and D. Christianson, "Wolf presence and increased willow consumption by Yellowstone elk: implications for trophic cascades," Ecology, vol. 90, no. 9, pp. 2454-2466, 2009.

[52] J. Winnie Jr. and S. Creel, "Sex-specific behavioural responses of elk to spatial and temporal variation in the threat of wolf predation," Animal Behaviour, vol. 73, no. 1, pp. 215-225, 2007.

[53] J. Belnap, D. Eldridge, J. H. Kaltenecker, S. Leonard, R. Rosentreter, and J. Williams, Biological Soil Crusts Ecology and Management, TR-1730-2, US Department of Interior, Bureau of Land Management, Denver, Colo, USA, 2001.

[54] N. E. West, "Western intermountain sagebrush steppe," in Temperate Deserts and Semi-Deserts, N. E. West, Ed., pp. 351373, Elsevier Scientific Publishing Company, Amsterdam, The Netherlands, 1983.

[55] J. Belnap and O. L. Lange, Eds., Biological Soil Crusts: Structure, Function, and Management, Springer, New York, NY, USA, 2003.

[56] O. L. Lange, E. D. Schulze, L. Kappen, U. Buschbom, and M. Evenari, "Adaptations of desert lichens to drought and extreme temperatures," in Environmental Physiology of Desert Ecosystems, N. F. Hadley, Ed., pp. 27-30, Dowden, Hutchinson and Ross, Stroudsberg, Pa, USA, 1975.

[57] J. A. R. Ladyman and E. Muldavin, Terrestrial Cryptogams of Pinyon-Juniper Woodlands in the Southwestern US: A Review, RM-GTR-280, US Department of Agriculture, Forest Service, Fort Collins, Colo, USA, 1996.

[58] A. J. Belsky and J. L. Gelbard, Livestock Grazing and Weed Invasions in the Arid West, Oregon Natural Desert Association, Bend, Ore, USA, 2000.

[59] G. Wuerthner, "The soil's living surface: biological crusts," in Welfare Ranching: The Subsidized Destruction of the American West, G. Wuerthner and M. Mattson, Eds., pp. 199-204, Island Press, Washington, DC, USA, 2004. 
[60] L. Deines, R. Rosentreter, D. J. Eldridge, and M. D. Serpe, "Germination and seedling establishment of two annual grasses on lichen-dominated biological soil crusts," Plant and Soil, vol. 295, no. 1-2, pp. 23-35, 2007.

[61] J. Belnap, "Potential role of cryptobiotic soil crust in semi-arid rangelands," in Proceedings-Ecology and Management of Annual Rangelands, S. B. Monsen and S. G. Kitchen, Eds., INT-GTR313, pp. 179-185, US Department of Agriculture, Forest Service, Boise, Idaho, USA, May 1992.

[62] E. F. Kleiner and K. T. Harper, "Environment and community organization in grasslands of Canyonlands National Park," Ecology, vol. 53, no. 2, pp. 299-309, 1972.

[63] M. L. Floyd, T. L. Fleischner, D. Hanna, and P. Whitefield, "Effects of historic livestock grazing on vegetation at chaco culture National Historic Park, New Mexico," Conservation Biology, vol. 17, no. 6, pp. 1703-1711, 2003.

[64] J. M. Ponzetti and B. P. McCune, "Biotic soil crusts of Oregon's shrub steppe: community composition in relation to soil chemistry, climate, and livestock activity," Bryologist, vol. 104, no. 2, pp. 212-225, 2001.

[65] R. N. Mack, "Invasion of Bromus tectorum L. into western North America: an ecological chronicle," Agro-Ecosystems, vol. 7, no. 2, pp. 145-165, 1981.

[66] US Bureau of Land Management, "Partners against weeds: an action plan for the Bureau of land management," Tech. Rep. BLM/MT/ST-96/003+1020, US Bureau of Land Management, Billings, Mont, USA, 1996.

[67] L. Ellison, "Influence of grazing on plant succession of Rangelands," The Botanical Review, vol. 26, no. 1, pp. 1-78, 1960.

[68] G. C. Lusby, "Effects of grazing on runoff and sediment yield from desert rangeland at Badger Wash in western Colorado, 1953-1973," US Geological Survey Water Supply Paper 1532-1, 1979.

[69] S. D. Warren, M. B. Nevill, W. H. Blackburn, and N. E. Garza, "Soil response to trampling under intensive rotation grazing," Soil Science Society of America Journal, vol. 50, no. 5, pp. 13361341, 1986.

[70] S. W. Trimble and A. C. Mendel, "The cow as a geomorphic agent-a critical review," Geomorphology, vol. 13, no. 1-4, pp. 233-253, 1995.

[71] G. P. Asner, A. J. Elmore, L. P. Olander, R. E. Martin, and T. Harris, "Grazing systems, ecosystem responses, and global change," Annual Review of Environment and Resources, vol. 29, pp. 261-299, 2004.

[72] W. P. Cottam and F. R. Evans, "A comparative study of the vegetation of grazed and ungrazed canyons of the Wasatch Range, Utah,” Ecology, vol. 26, no. 2, pp. 171-181, 1945.

[73] J. L. Gardner, "The effects of thirty years of protection from grazing in desert grassland," Ecology, vol. 31, no. 1, pp. 44-50, 1950.

[74] J. B. Kauffman, W. C. Krueger, and M. Vavra, "Effects of late season cattle grazing on riparian plant communities," Journal of Range Management, vol. 36, no. 6, pp. 685-691, 1983.

[75] G. F. Gifford and R. H. Hawkins, "Hydrologic impact of grazing on infiltration: a critical review," Water Resources Research, vol. 14, no. 2, pp. 305-313, 1978.

[76] T. L. Fleischner, "Ecological costs of livestock grazing in western North America," Conservation Biology, vol. 8, no. 3, pp. 629644, 1994.

[77] A. Jones, "Effects of cattle grazing on North American arid ecosystems: a quantitative review," Western North American Naturalist, vol. 60, no. 2, pp. 155-164, 2000.
[78] J. B. Kauffman, A. S. Thorpe, and E. N. J. Brookshire, "Livestock exclusion and belowground ecosystem responses in riparian meadows of eastern Oregon," Ecological Applications, vol. 14, no. 6, pp. 1671-1679, 2004.

[79] R. E. Ingham, J. A. Trofymow, E. R. Ingham, and D. C. Coleman, "Interactions of bacteria, fungi, and their nematode grazers: effects on nutrient cycling and plant growth," Ecological Monographs, vol. 55, no. 1, pp. 119-140, 1985.

[80] N. C. Brady and R. R. Weil, The Nature and Properties of Soils, Prentice-Hall, Upper Saddle River, NJ, USA, 12th edition, 1999.

[81] E. R. Ingham, Soil Biology Primer, US Department of Agriculture, Natural Resources Conservation Service, Soil Quality Institute, 1999.

[82] J. Skovlin, "Southern Africa's experience with intensive short duration grazing," Rangelands, vol. 9, pp. 162-167, 1987.

[83] J. L. Holechek, H. Gomes, F. Molinar, D. Galt, and R. Valdez, "Short-duration grazing: the facts in 1999," Rangelands, vol. 22, no. 1, pp. 18-22, 2000.

[84] J. Carter, B. Chard, and J. Chard, "Moderating livestock grazing effects on plant productivity, carbon and nitrogen storage," in Proceedings of the 17th Wildland Shrub Symposium, T. A. Monaco et al., Ed., pp. 191-205, Logan, Utah, USA, May 2010.

[85] H. Steinfeld, P. Gerber, T. Wassentaar, V. Castel, M. Rosales, and C. de Haan, Livestock's Long Shadow, Food and Agriculture Organization of the United Nations, Rome, Italy, 2006.

[86] R. Goodland and J. Anhang, "Livestock and climate change," World Watch, vol. 22, no. 6, pp. 10-19, 2009.

[87] Environmental Protection Agency, "Climate change overview of nitrous oxide," 2013, http://epa.gov/climatechange/ ghgemissions/gases/n2o.html.

[88] L. Reynolds, "Agriculture and livestock remain major sources of greenhouse gas emissions," 2013, http://www.worldwatch.org/ agriculture-and-livestock-remain-major-sources-greenhousegas-emissions-1.

[89] K. A. Johnson and D. E. Johnson, "Methane emissions from cattle," Journal of Animal Science, vol. 73, no. 8, pp. 2483-2492, 1995.

[90] L. Abend, "How cows (grass-fed only) could save the planet," Time Magazine, 2010.

[91] N. Pelletier, R. Pirog, and R. Rasmussen, “Comparative life cycle environmental impacts of three beef production strategies in the Upper Midwestern United States," Agricultural Systems, vol. 103, no. 6, pp. 380-389, 2010.

[92] R. R. Allmaras, H. H. Schomberg, J. Douglas C.L., and T. H. Dao, "Soil organic carbon sequestration potential of adopting conservation tillage in U.S. croplands," Journal of Soil and Water Conservation, vol. 55, no. 3, pp. 365-373, 2000.

[93] J. Grace, J. S. José, P. Meir, H. S. Miranda, and R. A. Montes, "Productivity and carbon fluxes of tropical savannas," Journal of Biogeography, vol. 33, no. 3, pp. 387-400, 2006.

[94] D. K. Benbi and J. S. Brar, "A 25-year record of carbon sequestration and soil properties in intensive agriculture," Agronomy for Sustainable Development, vol. 29, no. 2, pp. 257-265, 2009.

[95] R. F. Follett, J. M. Kimble, and R. Lal, Eds., The Potential of US Grazing Lands to Sequester Carbon and Mitigate the Greenhouse Effect, Lewis Publishers, Boca Raton, Fla, USA, 2001.

[96] C. Neely, S. Bunning, and A. Wilkes, "Review of evidence on drylands pastoral systems and climate change: implications and opportunities for mitigation and adaptation," Land and Water Discussion Paper 8, Food and Agriculture Organization of the United Nations, Rome, Italy, 2009. 
[97] S. Daryanto, D. J. Eldridge, and H. L. Throop, "Managing semiarid woodlands for carbon storage: grazing and shrub effects on above and belowground carbon," Agriculture, Ecosystems and Environment, vol. 169, pp. 1-11, 2013.

[98] D. P. Fernandez, J. C. Neff, and R. L. Reynolds, "Biogeochemical and ecological impacts of livestock grazing in semi-arid southeastern Utah, USA," Journal of Arid Environments, vol. 72, no. 5, pp. 777-791, 2008.

[99] D. D. Briske, N. F. Sayre, L. Huntsinger, M. Fernandez-Gimenez, B. Budd, and J. D. Derner, "Origin, persistence, and resolution of the rotational grazing debate: integrating human dimensions into rangeland research," Rangeland Ecology and Management, vol. 64, no. 4, pp. 325-334, 2011.

[100] D. M. Gammon, "An appraisal of short duration grazing as a method of veld management," Zimbabwe Agriculture Journal, vol. 81, pp. 59-64, 1984.

[101] PJ. O'Reagain and J. R. Turner, "An evaluation of the empirical basis for grazing management recommendations for Rangeland in southern Africa," Journal of the Grassland Society of Southern Africa, vol. 9, no. 1, pp. 38-49, 1992.

[102] D. D. Briske, B. T. Bestelmeyer, J. R. Brown, S. D. Fuhlendorf, and H. W. Polley, "The Savory method cannot green deserts or reverse climate change," Rangelands, vol. 35, no. 5, pp. 72-74, 2013.

[103] D. D. Briske, J. D. Derner, J. R. Brown et al., "Rotational grazing on Rangelands: reconciliation of perception and experimental evidence," Rangeland Ecology and Management, vol. 61, no. 1, pp. 3-17, 2008.

[104] J. T. Manley, G. E. Schuman, J. D. Reeder, and R. H. Hart, "Rangeland soil carbon and nitrogen responses to grazing," Journal of Soil and Water Conservation, vol. 50, no. 3, pp. 294298, 1995.

[105] J. M. Earl and C. E. Jones, "The need for a new approach to grazing management-is cell grazing the answer?" The Rangeland Journal, vol. 18, no. 2, pp. 327-350, 1996.

[106] G. Sanjari, H. Ghadiri, C. A. A. Ciesiolka, and B. Yu, "Comparing the effects of continuous and time-controlled grazing systems on soil characteristics in southeast Queensland," Australian Journal of Soil Research, vol. 46, no. 4, pp. 348-358, 2008.

[107] W. R. Teague, S. L. Dowhower, S. A. Baker, N. Haile, P. B. DeLaune, and D. M. Conover, "Grazing management impacts on vegetation, soil biota and soil chemical, physical and hydrological properties in tall grass prairie," Agriculture, Ecosystems and Environment, vol. 141, no. 3-4, pp. 310-322, 2011.

[108] K. T. Weber and B. S. Gokhale, "Effect of grazing on soil-water content in semiarid rangelands of southeast Idaho," Journal of Arid Environments, vol. 75, no. 5, pp. 464-470, 2011.

[109] H. W. van Poolen and J. R. Lacey, "Herbage response to grazing systems and stocking intensities," Journal of Range Management, vol. 32, no. 4, pp. 250-253, 1979.

[110] W. P. Clary and B. F. Webster, "Managing grazing of riparian areas in the Intermountain Region," Tech. Rep. GTR-INT-263, US Department of Agriculture, Forest Service, Ogden, Utah, USA, 1989.

[111] H. K. Orr, "Recovery from soil compaction on bluegrass range in the Black Hills," Transactions of the American Society of Agricultural and Biological Engineers, vol. 18, no. 6, pp. 10761081, 1975.

[112] A. J. Belsky, A. Matzke, and S. Uselman, "Survey of livestock influences on stream and riparian ecosystems in the western United States," Journal of Soil and Water Conservation, vol. 54, no. 1, pp. 419-431, 1999.
[113] T. Tucker Schulz and W. C. Leininger, "Differences in riparian vegetation structure between grazed areas and exclosures," Journal of Range Management, vol. 43, no. 4, pp. 295-299, 1990.

[114] E. J. Dyksterhuis, "Condition and management of rangeland based on quantitative ecology," Journal of Range Management, vol. 2, no. 3, pp. 104-115, 1949.

[115] E. F. Habich, "Ecological site inventory, technical reference 1734-7," Tech. Rep. BLM/ST/ST-01/003+1734, Bureau of Land Management, Denver, Colo, USA, 2001.

[116] D. S. Dobkin, A. C. Rich, and W. H. Pyle, "Habitat and avifaunal recovery from livestock grazing in riparian meadow system of the northwestern Great Basin," Conservation Biology, vol. 12, no. 1, pp. 209-221, 1998.

[117] S. L. Earnst, J. A. Ballard, and D. S. Dobkin, "Riparian songbird abundance a decade after cattle removal on Hart Mountain and Sheldon National Wildlife Refuges," in Proceedings of the 3rd International Partners in Flight Conference, C. J. Ralph and T. Rich, Eds., General Technical Report PSW-GTR-191, pp. 550558, US Department of Agriculture, Forest Service, Albany, Calif, USA, 2005.

[118] C. E. Bock and J. H. Bock, "Cover of perennial grasses in southeastern Arizona in relation to livestock grazing," Conservation Biology, vol. 7, no. 2, pp. 371-377, 1993.

[119] D. H. Stinner, B. R. Stinner, and E. Martsolf, "Biodiversity as an organizing principle in agroecosystem management: case studies of holistic resource management practitioners in the USA," Agriculture, Ecosystems and Environment, vol. 63, no. 2-3, pp. 199-213, 1997. 

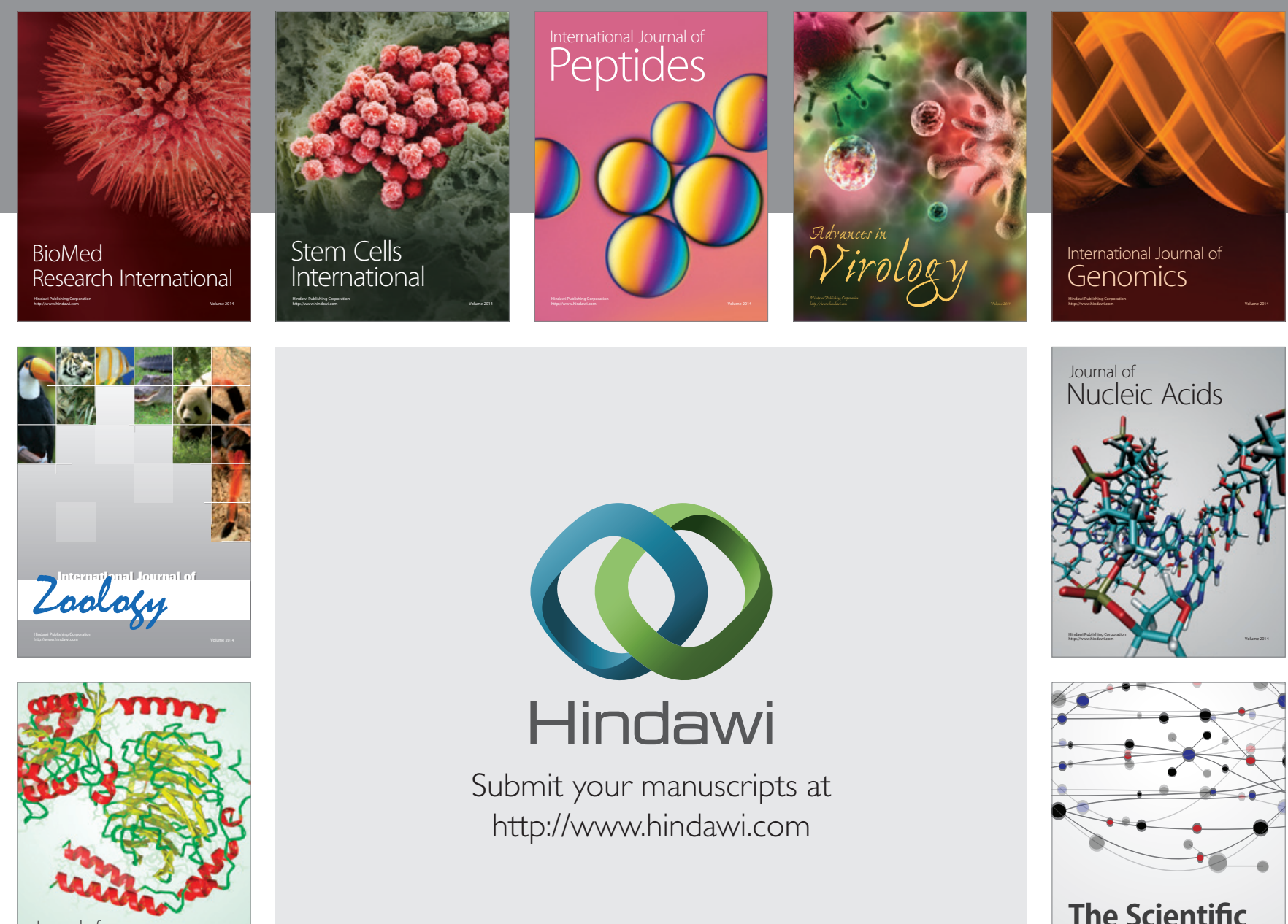

Submit your manuscripts at

http://www.hindawi.com

Journal of
Signal Transduction
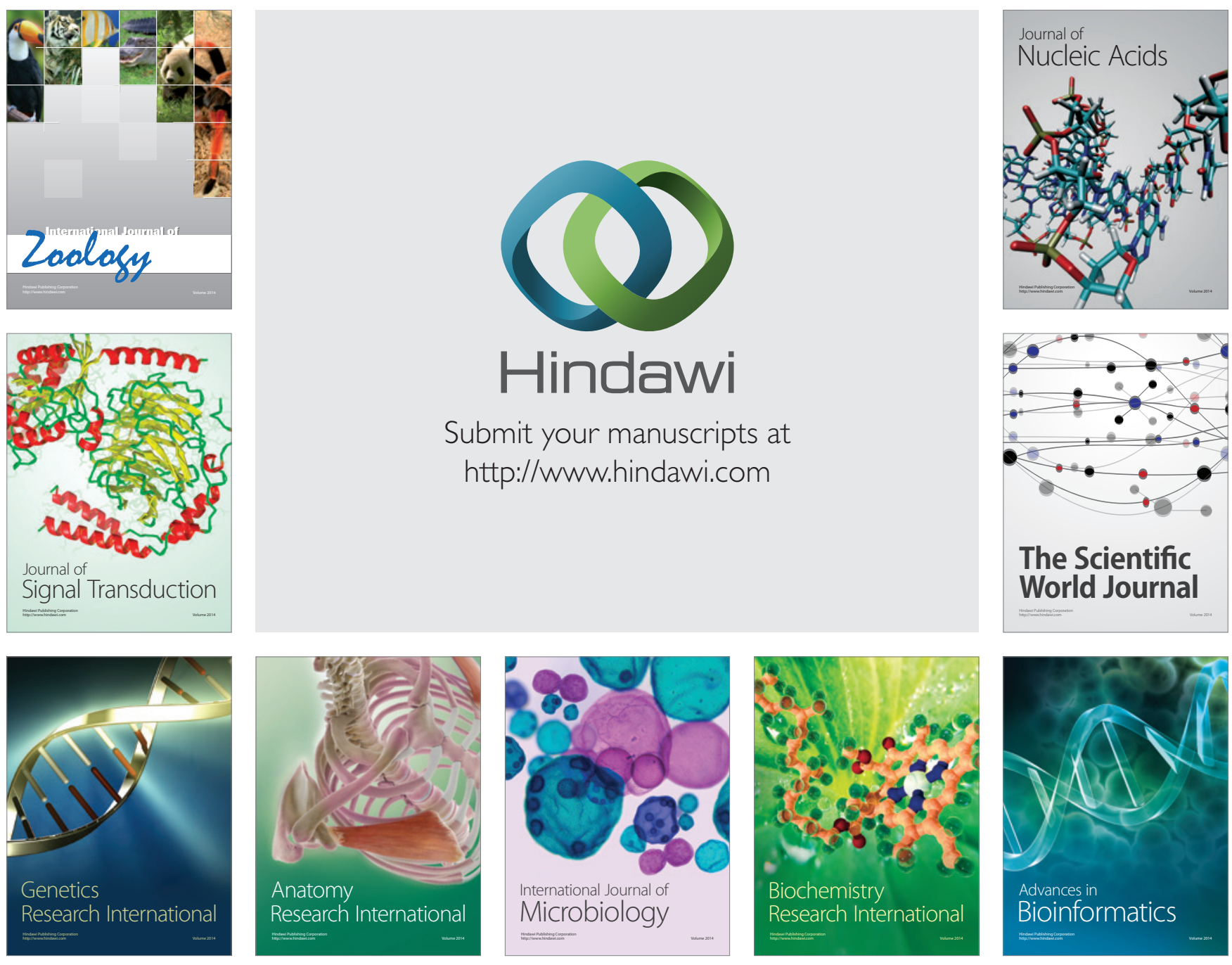

The Scientific World Journal
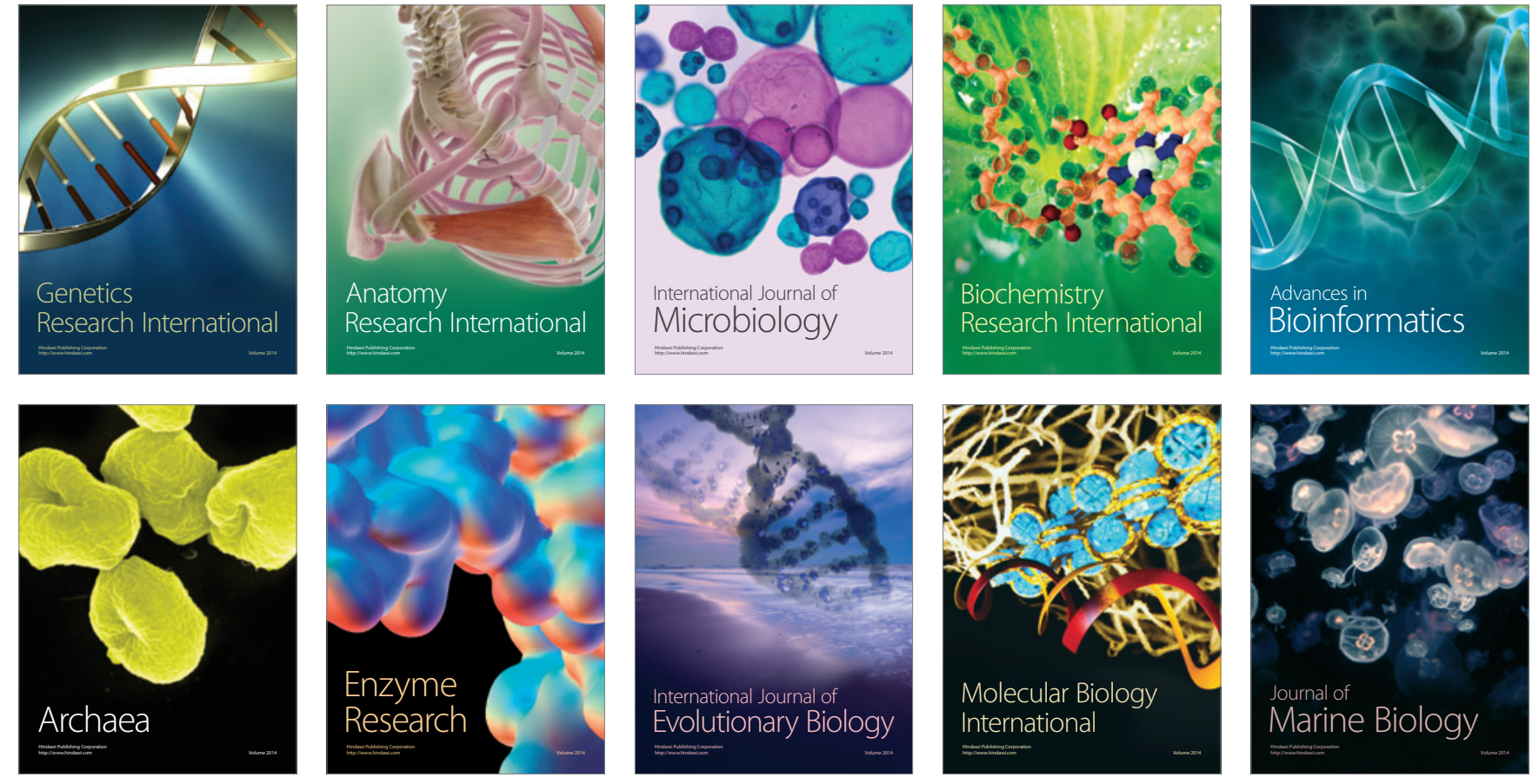